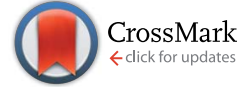

Cite this: RSC Adv., 2016, 6, 93590

Received 25th July 2016

Accepted 17th September 2016

DOI: $10.1039 / c 6 r a 18879 f$

www.rsc.org/advances

\section{The oleanolic acid derivative, 3-O-succinyl-28-O- benzyl oleanolate, induces apoptosis in B16-F10 melanoma cells via the mitochondrial apoptotic pathway}

\author{
Fernando J. Reyes-Zurita, ${ }^{\text {a }}$ Marta Medina-O'Donnell, ${ }^{\mathrm{b}}$ Rosa M. Ferrer-Martin, ${ }^{\mathrm{c}}$ \\ Eva E. Rufino-Palomares, ${ }^{a}$ Samuel Martin-Fonseca, ${ }^{\mathrm{b}}$ Francisco Rivas, ${ }^{\mathrm{b}}$ \\ Antonio Martínez, ${ }^{\mathrm{b}}$ Andrés García-Granados, ${ }^{\mathrm{b}}$ Amalia Pérez-Jiménez, ${ }^{\mathrm{a}}$ Leticia García- \\ Salguero, ${ }^{a}$ Juan Peragón, ${ }^{d}$ Khalida Mokhtari, ${ }^{\text {ae }}$ Pedro P. Medina, ${ }^{\text {af }}$ Andrés Parra ${ }^{\star b}$ \\ and José A. Lupiáñez ${ }^{\star a}$
}

\begin{abstract}
Oleanolic acid (1) is a pentacyclic triterpene present in olive pomace, which is known to induce apoptosis and to have anti-tumor properties; however, high concentrations of this product are necessary to produce cytotoxic effects. The 3-O-succinyl-28-O-benzyl oleanolate derivative (4) presents greater cytotoxicity and apoptosis effects than its natural precursor, oleanolic acid, or its benzyl derivative (2). This study examines the response of B16-F10 melanoma cells to treatment with compound 4, in comparison to 1 and 3 . Our studies show that treatment with 4 results in a significant inhibition of cell proliferation in a dosedependent manner and causes apoptotic cell death. At concentrations inhibiting cell growth by $50 \%$ and $80 \%$, compound 4 induces strong $G_{0} / G_{1}$ cell-cycle arrest, around $72-95 \%$ apoptosis, and mitochondrial disturbances confirmed by FACS analysis, which probably involve the activation of the intrinsic apoptotic route. Morphological changes including cell shrinkage, chromatin condensation, and loss of nuclear architecture were also observed. In this report, we demonstrated for the first time that in melanoma cancer cells, compound 4 exerts a significant anti-proliferation effect by inducing the apoptotic process with mitochondrial depolarization. These findings support the role of compound 4 as a new, potential therapeutic tool against aberrant cell proliferation in melanoma.
\end{abstract}

\section{Introduction}

Triterpenoid compounds are present in a wide range of plants that are used in traditional medicine, and are known to have anti-tumor properties. ${ }^{1-8}$ They are also involved in metabolic regulation, ${ }^{5,9-14}$ metabolic syndrome treatment ${ }^{15}$ and growth processes. ${ }^{16-22}$ All these compounds belong to a broad family of compounds obtained by cyclic reactions of 2,3-oxidosqualene. ${ }^{23}$

\footnotetext{
${ }^{a}$ Department of Biochemistry and Molecular Biology I, Faculty of Science, University of Granada, 18071 Granada, Spain. E-mail: ferjes@ugr.es; jlcara@ugr.es; Fax: +34 958 249945; Tel: +34 958 243252; +34958243089

${ }^{b}$ Department of Organic Chemistry, Faculty of Science, University of Granada, 18071 Granada, Spain. E-mail: aparra@ugr.es; Fax: +34 958 240480; Tel: +34 958240480 'Department of Cellular Biology, Faculty of Science, University of Granada, 18071 Granada, Spain

${ }^{d}$ Department of Experimental Biology, Biochemistry and Molecular Biology Section, University of Jaen, 23071 Jaen, Spain

${ }^{e}$ Department of Biology, Faculty of Sciences, Mohammed I University, BP 71760000 Oujda, Morocco

${ }^{f}$ Centre of Genomic and Oncologic Investigation (GENyO), Pfizer PharmaceuticalUniversity of Granada-Government of Andalusia, Technological Park of Health Sciences, 18016 Granada, Spain
}

Triterpenoids in plants, are secondary metabolites that are not essential for growth or development, but might contribute to their survival (e.g. phytoalexin), and are involved in the protection of plants against pathogens or pests. ${ }^{24}$ Currently, about one-fourth of all medications contain an active ingredient derived from plants. The most important triterpenoid structures are oleanane, ursane, lupane and dammarane. ${ }^{25}$

Oleanolic acid (1), an oleanane-type triterpenoid, is a natural compound that belongs to the pentacyclic triterpene family and is widely distributed in the plant kingdom. Oleanolic compounds for the current study were isolated in high amounts from the olive-pressing residues. Oleanolic acid (1) possesses many biological properties, including anti-inflammatory, antiHIV and cytotoxic activities. ${ }^{26}$ This compound (1) has also been described as an inhibitor of skin tumor progression. ${ }^{26}$ This natural compound (1) provides a very useful scaffold for obtaining derivatives with improved biological properties. ${ }^{27-29}$ Our research group has performed a series of systematic chemical modifications of $\mathbf{1}$ to improve its biological activities..$^{\mathbf{3 0} 31}$

Most pentacyclic triterpenes are not sufficiently water soluble, which hampers biological tests, and results in their low 
bioavailability. ${ }^{32-34}$ One option to improve the solubility of these triterpene compounds is to semi-synthesize derivatives by attaching diverse functional groups to the hydroxyl groups of the A ring and/or to the carboxyl group at C-28. Our group has demonstrated that acyl oleanolic acid derivatives with a polar dicarboxylic fragment as the acyl group on C-3 present major cytotoxic and apoptotic effects, compared to their precursor (1). ${ }^{30,31,35}$ Chemical modifications of natural triterpenoid compounds have resulted in products that have improved biological activities, compared to their natural precursors. Our group has shown that several triterpene derivatives, with monoor di-peptidyl groups at C-28, and acyl groups at $\mathrm{C}-2$ or $\mathrm{C}-2 / \mathrm{C}-3$ of the triterpene skeleton, exhibit cytotoxic properties on B16F10, HT29, or Hep G2 cancer cell lines. ${ }^{30}$

Apoptosis, or programmed cell death, is defined as an active physiological process of cell self-destruction. Agents that suppress the proliferation of malignant cells by inducing apoptosis may be useful in both the chemoprevention and chemotherapy of cancer. Two major pathways have been described during apoptotic activation: the mitochondrial or intrinsic pathway, and the death-receptor or extrinsic pathway.

The intrinsic pathway involves mitochondrial disruption and a decrease in the mitochondrial membrane potential. ${ }^{35,36}$ This apoptotic route involves the mitochondria-dependent activation of initiator caspases, which in turn activate downstream executive caspases, such as caspase-3. Our research group has demonstrated that the oleanane-type triterpenoid, maslinic acid, selectively induces anti-tumor and pro-apoptotic effects in HT29 colon cancer cells. ${ }^{1}$ The activation of the intrinsic apoptotic pathway is mediated by mitochondrial Bax activation and Bcl-2 inhibition, resulting in the mitochondrial membrane disruption, increase of ROS, activation of caspase-9, caspase-3 and caspase-7., ${ }^{2,3}$ Maslinic acid induces differentiation in this cell line before the activation of the apoptotic process. ${ }^{\mathbf{1 , 2}}$

The extrinsic death-receptor pathway is triggered by the death ligand through the formation of the death-inducing signaling complex that results in caspase-8 and caspase-10 activation, which initiates the downstream apoptotic signaling. ${ }^{32,37,38}$ Maslinic acid also produces the direct activation of apoptosis through an extrinsic apoptotic pathway in Caco-2 colon cancer cells, involving caspase-8 activation, bid cleavage, caspase- 9 and caspase- 3 activation, with a lower cellcycle arrest ${ }^{5}$ caspase- 9 and ROS generation were not observed. ${ }^{8}$

The evaluation of mitochondrial potential at the cytotoxic and apoptotic concentrations can help to determine the possible molecular mechanism involved in the apoptotic response. ${ }^{31}$ We describe here the anti-cancer effects of three oleanolic acid derivatives. In order to increase the apoptotic activity of these products, compound $\mathbf{1}$ was benzylated to obtain the 28-benzyl derivative (2) and the 3-succinyl-28-benzyl derivative (4) (Fig. 1).

Following treatment with $\mathbf{4}$, a potent apoptotic and antiproliferation effect in melanoma B16-F10 cancer cells, including cell-cycle arrest in the $\mathrm{G}_{0}$ phase with the disappearance of $S$ phase, was observed. The compound $\mathbf{4}$ also produced over $90 \%$ of apoptosis induction through mitochondrial disturbances, with clear morphological changes in the nucleus

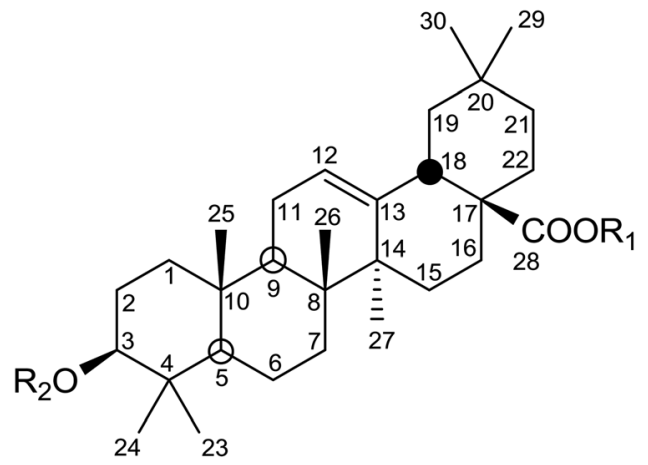

1: $\mathrm{R}_{1}=\mathrm{R}_{2}=\mathrm{H}$

2: $\mathrm{R}_{1}=\mathrm{Bn}, \mathrm{R}_{2}=\mathrm{H}$

3: $\mathrm{R}_{1}=\mathrm{H}, \mathrm{R}_{2}=$ Succinyl

4: $R_{1}=B n, R_{2}=$ Succinyl

Fig. 1 Structures of the triterpene skeleton of oleanolic acid (1) and its derivatives: 28-O-benzyl oleanolate (2), 3-O-succinyl oleanolic acid (3), and 3-O-succinyl-28-O-benzyl oleanolic acid (4).

and the cytoplasm. On the other hand, compound 2 produced $40 \%$ of apoptosis induction, similar to the natural triterpene, without affecting the mitochondrial membrane potential.

Agents that suppress the proliferation of malignant cells by inducing apoptosis could be useful in cancer therapy. Consequently, compound $\mathbf{4}$ may provide a useful new therapeutic strategy for skin melanoma.

\section{Experimental section}

\subsection{Apparatus and materials}

The purity of the compounds was determined by a Waters Acquity UPLC system (ultra-performance liquid chromatography) coupled with a Waters Synapt G2 HRMS spectrometer (high-resolution mass spectra) with ESI (electrospray ionization). The purities of all compounds were confirmed to be $\geq 95 \%$. Measurements of NMR spectra $\left(300.13 \mathrm{MHz}{ }^{1} \mathrm{H}\right.$ and $75.47 \mathrm{MHz}{ }^{13} \mathrm{C}$ ) were made in $\mathrm{CDCl}_{3}$ (which also provided the lock signal) using a VARIAN Inova unity (300 MHz ${ }^{1} \mathrm{H}$ NMR). The ${ }^{13} \mathrm{C}$ chemical shifts were assigned with the aid of distortionless enhancement by polarization transfer (DEPT) using a flip angle of $135^{\circ}$. IR spectra were recorded on a MATTSON SATELLITE FTIR spectrometer. Optical rotations were measured on a Perkin-Elmer 241 polarimeter at $25{ }^{\circ} \mathrm{C}$. Melting points (mp) were determined using a Kofler (Reichter) apparatus and were uncorrected.

All reaction solvents and chromatography solvents were distilled prior to use. Commercially available reagents were used without further purification. Merck silica-gel 60 aluminium sheets (ref. 1.16835) were used for TLC, and spots were rendered visible by spraying with $\mathrm{H}_{2} \mathrm{SO}_{4}-\mathrm{AcOH}$, followed by heating to $120{ }^{\circ} \mathrm{C}$, and were also visualized under UV at 254 nm. Merck silica-gel 60 (0.040-0.063 mm, ref. 1.09385) was used for flash chromatography. $\mathrm{CH}_{2} \mathrm{Cl}_{2}$ (Fisher, ref. D/1852/17), $\mathrm{CHCl}_{3}$ (Fisher, ref. C/4960/17), or $n$-hexane (Merck, ref. 
1.04374), with increasing amounts of acetone (Fisher, ref. A/ 0600/17), $\mathrm{MeOH}$ (Fisher, ref. M/4000/17), or EtOAc (Fisher, ref. $\mathrm{E} / 0900 / 17$ ), were used as eluents (all the solvents were of analytical reagent-grade purity).

The plant material, a specimen of the plant of Olea europaea (order Lamiales, family Oleaceae) was collected in Almegijar, Granada, Spain in May 2001. This plant was identified by Laura Baena from the herbarium of the University of Granada. A voucher specimen (53489-1-1) was deposited at the University of Granada Herbarium, Granada, Spain.

\subsection{Synthesis and characterization of 3-O-succinyl-28-O- benzyl oleanolate and its intermediates (1-4)}

2.2.1. Oleanolic acid (1). This compound (1) was isolated from solid olive-oil-production wastes, which were extracted with hexane, using a Soxhlet extractor. Hexane extracts were concentrated and $\mathbf{1}$ was purified from these residues by column chromatography over silica gel, eluting with a $\mathrm{CHCl}_{3} / \mathrm{MeOH}$ or $\mathrm{CH}_{2} \mathrm{Cl}_{2}$ /acetone mixture of increasing polarity; ${ }^{39,40}$ a white solid, mp 306-308 ${ }^{\circ} \mathrm{C} ;[\alpha]_{\mathrm{D}}=+80\left(\mathrm{c} 1, \mathrm{CHCl}_{3}\right)$; IR (KBr) $\nu_{\text {max }}: 3438$, 2930, 2869, $1690 \mathrm{~cm}^{-1}$ was obtained. The compound (1) presents a mass spectrum that corresponds to a molecular formula of $\mathrm{C}_{30} \mathrm{H}_{48} \mathrm{O}_{3}$ and therefore, has a molecular weight of $456 \mathrm{amu}$. In its ${ }^{1} \mathrm{H}$ NMR spectrum, the more deshielded signals appeared at $5.25 \mathrm{ppm}\left(1 \mathrm{H}, \mathrm{dd}, J_{1}=J_{2}=3.6 \mathrm{~Hz}\right)$ for the olefinic proton of C$12,3.16 \mathrm{ppm}\left(1 \mathrm{H}, \mathrm{dd}, J_{1}=4.8 \mathrm{~Hz}, J_{2}=11.2 \mathrm{~Hz}\right)$ for the equatorial proton of $\mathrm{C}-3$ geminal to the hydroxyl at this position and $2.84 \mathrm{ppm}\left(1 \mathrm{H}, \mathrm{dd}, J_{1}=3.7 \mathrm{~Hz}, J_{2}=13.6 \mathrm{~Hz}\right)$ for the allylic hydrogen of C-18. Finally, the signals of the seven angular methyl groups were observed at $\delta_{\mathrm{H}} 1.15$ (s, 3H C-27), $0.97(\mathrm{~s}, 3 \mathrm{H}$ C-23), 0.93 (s, 3H C-25 and 3H C-30), 0.90 (s, 3H C-29), 0.80 (s, $3 \mathrm{H} \mathrm{C}-26)$ and 0.77 (s, 3H, C-24). This structure was confirmed by studying the ${ }^{13} \mathrm{C}$ NMR, COSY, HMBC and HMQC mono- and bidimensional spectra exhaustively, and is completely concordant with those in the literature.

2.2.2. 28-O-Benzyl oleanolate $(2)$. $\mathrm{BnCl}(418 \mu \mathrm{L})$ was added in a $2: 1$ ratio to a solution of $1(912 \mathrm{mg}, 2 \mathrm{mmol})$ in DMF $(8 \mathrm{~mL})$ with $\mathrm{K}_{2} \mathrm{CO}_{3}(0.61 \mathrm{~g})$. The reaction was stirred for $4 \mathrm{~h}$ at $55{ }^{\circ} \mathrm{C}$. The mixture was diluted with water and extracted with $\mathrm{CH}_{2} \mathrm{Cl}_{2}$, and the organic layer was dried with anhydrous $\mathrm{Na}_{2} \mathrm{SO}_{4}$. The solvent was removed under reduced pressure, and the residue was purified by column chromatography using $\mathrm{CH}_{2} \mathrm{Cl}_{2}$ /acetone $(10: 1)$ to give 2 as a white solid (710 mg, 83\%) (Scheme 1), ${ }^{41}$ with mp 221-223 ${ }^{\circ} \mathrm{C} ;[\alpha]_{\mathrm{D}}+64\left(c 1, \mathrm{CHCl}_{3}: \mathrm{MeOH}, 2: 1\right)$; IR $\nu_{\max }$ $(\mathrm{KBr}) / \mathrm{cm}^{-1}$ : 3371, 2940, 2891, 1668. This compound has a molecular mass of $561 \mathrm{amu}$ and in its ${ }^{1} \mathrm{H}$ NMR spectrum, in addition to the above mentioned signals, at $7.48 \mathrm{ppm}(\mathrm{m}, 5 \mathrm{H})$ it presents the signal of the aromatic protons and at $5.00 \mathrm{ppm}$ $(2 \mathrm{H}, \mathrm{AB}$ system, $J=12.0 \mathrm{~Hz})$ it presents the signal of the methylene benzyl group. Moreover, the more significant signals of compound 2 in its ${ }^{13} \mathrm{C}$ NMR spectrum are shown at 177.6 ppm (C-28, this signal is shielded from $184.5 \mathrm{ppm}$ for OA as a consequence of the benzyl ester formation), $136.7 \mathrm{ppm}$ (a quaternary carbon of the benzyl group), around $128.0 \mathrm{ppm}$ (five methane carbons of the benzyl group) and $66.1 \mathrm{ppm}$ (methylene group of the benzyl group).
2.2.3. 3-O-Succinyl oleanolic acid (3). Succinic anhydride (236 mg, $2 \mathrm{mmol}$ ) was slowly added to a solution of $\mathbf{1}$ (456 mg, 1 $\mathrm{mmol}$ ) in pyridine ( $5 \mathrm{~mL})$. The reaction was maintained at room temperature while stirring for $24 \mathrm{~h}$. Cold water was added to the reaction mixture, followed by an extraction with $\mathrm{CH}_{2} \mathrm{Cl}_{2}$, and the organic layer was dried with anhydrous $\mathrm{Na}_{2} \mathrm{SO}_{4}$. The solvent was removed under reduced pressure and the residue was purified by column chromatography using $\mathrm{CH}_{2} \mathrm{Cl}_{2}$ /acetone $(10: 1)$ to give 3 as a white solid (90\%) (Scheme 1$),{ }^{42}$ with $\mathrm{mp}$ 190-192 ${ }^{\circ} \mathrm{C} ;[\alpha]_{\mathrm{D}}+49\left(c 1\right.$ in $\left.\mathrm{CHCl}_{3}: \mathrm{MeOH}, 2: 1\right)$; IR $\nu_{\max }(\mathrm{KBr}) /$ $\mathrm{cm}^{-1}$ : 3394, 3018, 2854 and 1712. This compound has a molecular mass of 565 amu. The main spectroscopic difference between the succinylated compound (3) and the corresponding substrate (1) was the deshielding of the signal of the $\mathrm{H}-3$ geminal proton because of the presence of the succinyl group on $\mathrm{C}-3$; in this sense, this signal was situated at $\delta_{\mathrm{H}} 3.19$ for (1) and $\delta_{\mathrm{H}} 4.51$ for (3). Moreover, in the ${ }^{13} \mathrm{C}$ NMR spectrum of 3 , the four signals of the four carbons of the succinyl group appear at $\delta_{\mathrm{H}} 178.6$ and 171.8 , due to free carboxylic group and carboxylate group, and $\delta_{\mathrm{H}} 29.6$ and 29.4, corresponding to the two methylene groups. The other signals in this spectrum of this compound remain practically unaltered.

2.2.4. 3-O-Succinyl-28-O-benzyl oleanolate (4). $\mathrm{BnCl}(210$ $\mu \mathrm{L}$ ) was added in a $2: 1$ ratio to a solution of 3-O-succinyl oleanolic acid (3, $556 \mathrm{mg}, 1 \mathrm{mmol})$ in $\mathrm{DMF}(4 \mathrm{~mL})$ with $\mathrm{K}_{2} \mathrm{CO}_{3}(0.30$ $\mathrm{g})$. The reaction was stirred for $4 \mathrm{~h}$ at $55{ }^{\circ} \mathrm{C}$. The mixture was diluted with water and extracted with $\mathrm{CH}_{2} \mathrm{Cl}_{2}$, and the organic layer was dried with anhydrous $\mathrm{Na}_{2} \mathrm{SO}_{4}$. The solvent was removed under reduced pressure, and the residue was purified by column chromatography, using $\mathrm{CH}_{2} \mathrm{Cl}_{2}$ /acetone $(10: 1)$ to give 4 (Scheme 1$)$ as a colourless oil, $[\alpha]_{\mathrm{D}}+38(c 1$ in $\mathrm{CHCl}_{3}: \mathrm{MeOH}, 2$ : 1); IR $\nu_{\max }\left(\right.$ film) $/ \mathrm{cm}^{-1}: 3377,3020,2859$ and 1720. This compound (4) has a molecular mass of 670 amu and presented the above mentioned NMR spectroscopic characteristics when both functional groups of the molecule were modified as a succinyl derivative at C-3 (deshielding of $\mathrm{H}-3$ from $3.19 \mathrm{ppm}$ to $4.48 \mathrm{ppm}$, due to the esterification the hydroxyl group at this position) and as a benzyl ester at C-28 (appearance of the methylene group signal at $5.05 \mathrm{ppm}$ and a multiplet signal at $7.31 \mathrm{ppm})$. On the other hand, all the carbons of the two new functional groups at C-3 and C-28 appear adequately in its ${ }^{13} \mathrm{C}$ NMR spectrum. This bifunctional compound (4) was also obtained by succinylation of 28-benzyl oleanolate (2). Succinic anhydride (73 $\mathrm{mg}, 0.732 \mathrm{mmol})$ was slowly added to a solution of $2(100 \mathrm{mg}, 0.183 \mathrm{mmol})$ in pyridine $(2 \mathrm{~mL})$. The mixture was treated as described above for the succinylation of $\mathbf{1}$ and thus, compound $\mathbf{4}$ was again formed. ${ }^{31}$

\subsection{Anti-cancer test on skin melanoma cancer cells}

The different compounds used in cell treatment (1, 2, 3, and 4) (Fig. 1) were dissolved before use at $10 \mathrm{mg} \mathrm{mL}^{-1}$ in $50 \%$ DMSO and $50 \%$ PBS. The stock solution was frozen and stored at -20 ${ }^{\circ} \mathrm{C}$. Prior to the experiments, this solution was diluted with cellculture medium. Apoptosis, cell-cycle, mitochondrialmembrane potential and Hoescht-staining were measured at the $\mathrm{IC}_{50}$ and $\mathrm{IC}_{80}$ concentrations (concentrations causing $50 \%$ 

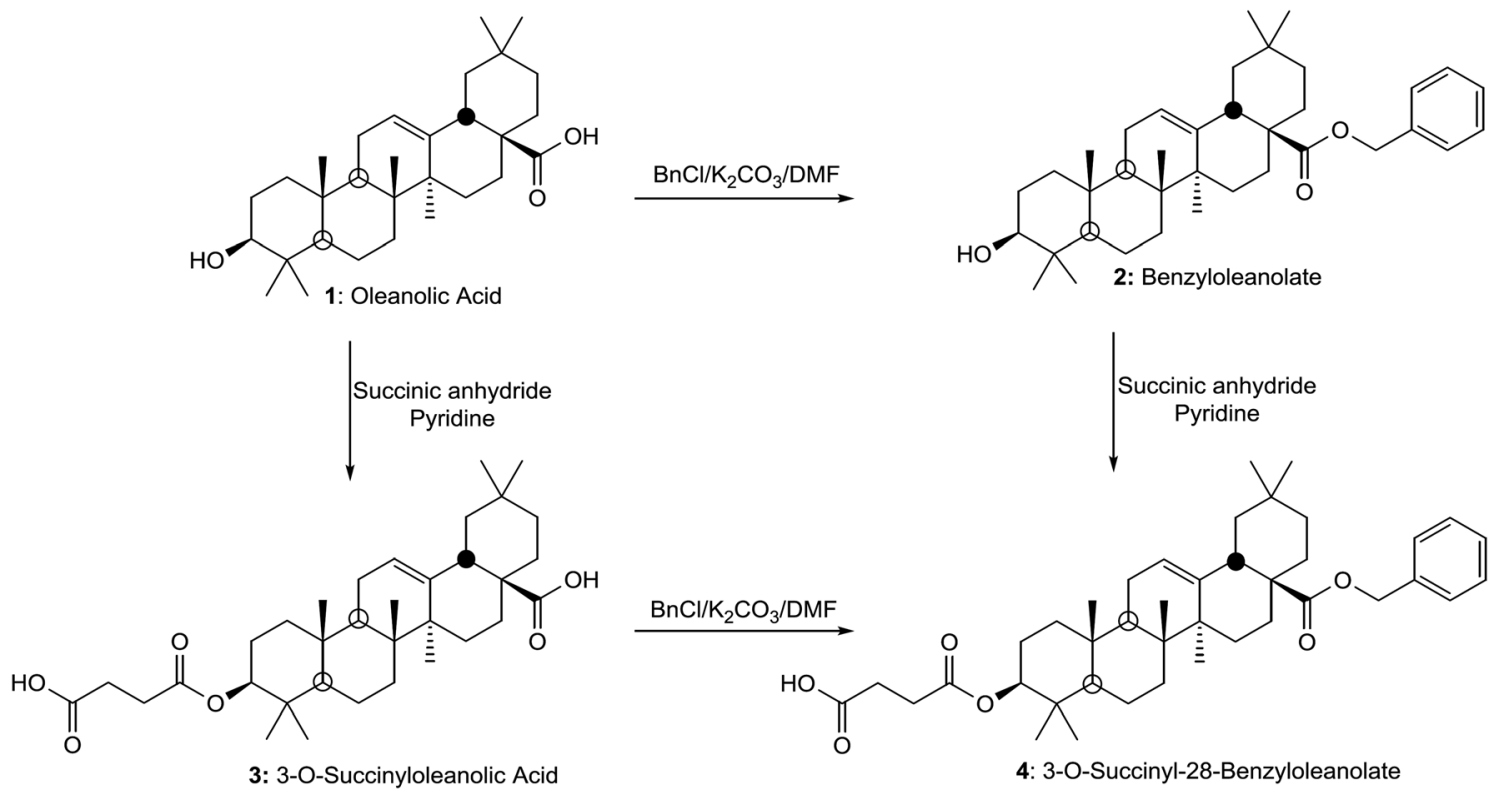

Scheme 1 Synthetic route to 3-O-succinyl-28-O-benzyl oleanolate. Oleanolic acid (1) is treated with benzyl chloride to achieve 28-O-benzyl oleanolate (2), or it can be succinylated with succinyl anhydride to achieve 3 -O-succinyl oleanolic acid (3). Compound 2 is then succinylated, and 3 is benzylated, following similar conditions as described for 1 , to obtain the 3 -O-succinyl-28-O-benzyl oleanolate (4).

and $80 \%$ reduction in growth). All the experiments were compared to the controls after $72 \mathrm{~h}$ of treatment.

2.3.1. Cell-proliferation activity assay. Murine melanoma cell line B16-F10 (ECACC CRL-6475) was cultured in DMEM supplemented with $2 \mathrm{mM}$ glutamine, $10 \%$ heat-inactivated FCS, 10000 units per $\mathrm{mL}$ of penicillin and $10 \mathrm{mg} \mathrm{mL}^{-1}$ of streptomycin, and incubated at $37^{\circ} \mathrm{C}$ in an atmosphere of $5 \% \mathrm{CO}_{2}$, and $95 \%$ humidity. Sub-confluent monolayer cells were used in all experiments.

The cell line was provided by the cell bank of the University of Granada, Spain. B16-F10 cells were derived from a melanoma from the skin of a C57BL/6 strain mouse, and are adherent cells with fibroblast-like appearance, capable of producing melanin, and forming metastatic tumor nodules in the lung upon injecting mice. ${ }^{43}$ The clone F10 of B16 cells are susceptible to lysis mediated by syngeneic lymphocytes. ${ }^{44}$

The effect of the treatment with products $\mathbf{1}, \mathbf{2}, \mathbf{3}$, and $\mathbf{4}$ on the proliferation of B16-F10 melanoma cells was measured using the MTT assay (Sigma, MO, USA), which is based on the ability of live cells to cleave the tetrazolium ring, thus producing formazan, which absorbs at $570 \mathrm{~nm}$. Cell viability was determined by measuring the absorbance of the MTT dye staining of living cells. For this assay, $11 \times 10^{3}$ B16-F10 cells were grown in a 96well plate and incubated with the different derivatives $(0-80 \mu \mathrm{g}$ $\left.\mathrm{mL}^{-1}\right)$. After $72 \mathrm{~h}, 100 \mathrm{~mL}$ of MTT solution $\left(0.5 \mathrm{mg} \mathrm{mL}^{-1}\right)$ were added to each well. After $2 \mathrm{~h}$ of incubation, the cells were washed twice with PBS, and formazan was resuspended in 100 $\mu \mathrm{L}$ DMSO.

Relative cell viability, with respect to untreated control cells, was measured based on the absorbance at $550 \mathrm{~nm}$ on an ELISA plate reader (Tecan Sunrise MR20-301, TECAN, Austria). Derivatives that showed high cytotoxicity were used to perform apoptosis, cell-cycle, mitochondrial-membrane potential analysis and studies on morphological changes with Hoeschtstaining.

2.3.2. Cell-cycle analysis. The cell-cycle was analyzed with flow cytometry by using a fluorescence-activated cell sorter (FACS) at $488 \mathrm{~nm}$ in an Epics XL flow cytometer (Coulter Corporation, Hialeah, FL, USA), as described previously. ${ }^{34}$ For this assay $11 \times 10^{4}$ B16-F10 cells per well were plated in 12 well plates with $2 \mathrm{~mL}$ of medium. After $24 \mathrm{~h}$, the different compounds $(1,2$, and 4$)$ were added and the cells were incubated for $72 \mathrm{~h}$. The doses used for each compound were their respective $\mathrm{IC}_{50}$ and $\mathrm{IC}_{80}$ values as determined by the cell proliferation activity assay.

Cells were washed twice with PBS and harvested by trypsinization, resuspended in TBS $1 \times(10 \mathrm{mM}$ Tris, $150 \mathrm{mM} \mathrm{NaCl})$ and subsequently, Vindelov buffer (100 mM Tris, $100 \mathrm{mM} \mathrm{NaCl}$, $10 \mathrm{mg} \mathrm{mL}{ }^{-1}$ RNase, $1 \mathrm{mg} \mathrm{mL}{ }^{-1}$ propidium iodide [PI], $\mathrm{pH} 8$ ) were added. Just before measurements, the total DNA content was stained with $1 \mathrm{mg} \mathrm{mL}{ }^{-1}$ PI. The cell-cycle was analyzed using Multicycle software. The data were analyzed to determine the percentage of cells at each phase of the cell-cycle $\left(\mathrm{G}_{0} / \mathrm{G}_{1}, \mathrm{~S}\right.$ and $\mathrm{G}_{2} / \mathrm{M}$ ). Approximately $10 \times 10^{3}$ cells were analyzed in each experiment. All experiments were performed three times with two replicates per experiment.

2.3.3. Annexin VeFICT/PI flow-cytometric analysis. The extent of apoptosis was analyzed with flow-cytometry by using a FACScan flow-cytometer (fluorescence-activated cell sorter, Coulter Corporation, Hialeah, FL, USA). Briefly, $11 \times 10^{4}$ B16F10 cells were plated in 12 well plates with $2 \mathrm{~mL}$ of medium, following treatment with the different compounds $(\mathbf{1}, \mathbf{2}$, and $\mathbf{4})$, for $72 \mathrm{~h}$ at the $\mathrm{IC}_{50}$ and $\mathrm{IC}_{80}$ concentrations calculated previously. The cells were collected and resuspended in binding 
buffer (10 mM HEPES/NaOH, pH 7.4, $140 \mathrm{mM} \mathrm{NaCl,} 2.5 \mathrm{mM}$ $\left.\mathrm{CaCl}_{2}\right)$. Annexin VeFITC conjugate $\left(1 \mu \mathrm{g} \mathrm{mL}{ }^{-1}\right)$ was added, followed by incubation for $30 \mathrm{~min}$ at RT in the dark. Just before FACS analysis, the cells were stained with $20 \mu \mathrm{L}$ of $1 \mathrm{mg} \mathrm{mL}^{-1}$ PI solution. In each experiment, approximately $20 \times 10^{3}$ cells were analyzed and the experiment was performed twice in triplicate.

2.3.4. Flow-cytometric analysis of the mitochondrialmembrane potential. Oxidative damage was studied by flowcytometric analysis of the mitochondrial membrane potential using dihydrorhodamine 123 (DHR), which is oxidized to the highly fluorescent product, rhodamine (Rh123). The formation of Rh123 can be monitored by fluorescence spectroscopy, using excitation and emission wavelengths of 500 and $536 \mathrm{~nm}$, respectively. The intracellular measurement of the mitochondrial membrane potential was made by the cytometric determination of Rh123. The intensity of fluorescence from Rh123 and PI was determined using a FACScan flow-cytometer (fluorescence-activated cell sorter, Coulter Corporation, Hialeah, FL, USA).

Similar to the apoptosis assays, $11 \times 10^{4}$ B16-F10 cells were plated in 12-well plates and treated with the different compounds $(1,2$, and 4$)$ at their $\mathrm{IC}_{50}$ and $\mathrm{IC}_{80}$ concentrations. Following the treatment, the medium was removed and fresh medium with DHR at a final concentration of $5 \mu \mathrm{g} \mathrm{mL}{ }^{-1}$ was added. After $30 \mathrm{~min}$ of incubation, the medium was removed and the cells were washed and resuspended in PBS with $5 \mu \mathrm{g}$ $\mathrm{mL}^{-1}$ of PI.

2.3.5. Hoechst-staining. The morphological changes were analyzed by fluorescent microscopy, using Hoechst staining. For this, $11 \times 10^{4}$ B16-F10 cells were plated onto a coverslip in 12-well plates. After $24 \mathrm{~h}$, different compounds (1, 2, and 4) were added and the cells were incubated for a further $72 \mathrm{~h}$ at their respective $\mathrm{IC}_{50}$ and $\mathrm{IC}_{80}$ values. The cells were washed twice with PBS and treated with cold $100 \% \mathrm{MeOH}$ for $3 \mathrm{~min}$. Subsequently, the cells were washed in PBS and incubated in $500 \mu \mathrm{L}$ of Hoechst solution ( $50 \mathrm{ng} \mathrm{mL}{ }^{-1}$ ) in PBS for 15 min in the dark. The samples were prepared with mounting medium, Mowiol, and visualized using fluorescence microscopy (DMRB, Leica Microsystems, Wetzlar, Germany) with a DAPI filter.

\subsection{Statistical analysis}

Statistical analyses were performed with the GraphPad Prism 5.0 software. All quantitative data are summarized as the mean \pm standard deviation (SD) or mean standard error (SEM). For each assay, Student's $t$ test was used for statistical comparison with the untreated control cells. A limit of $p \leq 0.05$ was considered to be statistically significant. Key: $p<0.05\left(^{*}\right), p \leq$ $0.01(* *)$ and $p \leq 0.001(* * *)$. All data shown here are representative of at least three independent experiments performed in duplicate.

\section{Results and discussion}

\subsection{Chemistry synthesis}

3.1.1. Synthetic route to 3-O-succinyl-28-O-benzyl oleanolate. The synthetic route to the target 3-O-succinyl-28-O- benzyl oleanolate is depicted in Scheme 1. The starting compound 1, oleanolic acid (3 $\beta$-hydroxyolean-12-en-28-oic acid) is a natural compound present in different plants. For the current study, this compound was isolated from the olivepressing residues by extraction processes with different solvents. The benzylation of $\mathbf{1}$ by treatment with benzyl chloride in DMF to achieve 28-O-benzyl oleanolate (2), was carried to protect the carboxylic group at $\mathrm{C}-28$ of the oleanane skeleton and to obtain a derivative that has an aromatic group attached at this position. Subsequently, the succinylation process was performed by treating (1) with succinyl anhydride (2:1 ratio) in pyridine for $24 \mathrm{~h}$ at RT; 3-O-succinyl oleanolic acid (3) was obtained in high yield. Finally, 28-O-benzyl oleanolate (2) was succinylated following similar conditions to those indicated above for 1 and thus, the bifunctional derivative 3-O-succinyl28-O-benzyloleanolate (4) was obtained in high yield. This bifunctional derivative (4) of $\mathbf{1}$ was also obtained by succinylation of 28-benzyloleanolate (2) in similar conditions, as previously indicated. After the target compound was successfully prepared, the structural characteristics of the compound were examined by UV, MS and NMR spectroscopy.

\subsection{Anti-cancer activities}

3.2.1. Inhibition of B16-F10 skin-melanoma cell proliferation. In this work, the potential cytotoxic effect of these semisynthesized derivatives $(\mathbf{2}, \mathbf{3}, \mathbf{4})$ was examined via the proliferation of the B16-F10 murine melanoma cell line, compared to its natural precursor (1), using the MTT assay. B16-F10 cells were treated with increasing doses of each compound. Their viability was determined by formazan dye uptake and expressed as a percentage of untreated control cell proliferation. Compounds 1, 2 and 4 induced a dose-dependent decrease in viable formazan accumulating cells after $72 \mathrm{~h}$ of treatment, ranging from 0 to $80 \mu \mathrm{g} \mathrm{mL} \mathrm{m}^{-1}$.

The concentration (expressed in $\mu \mathrm{g} \mathrm{mL}^{-1}$ ) of products required for $50 \%$ and for $80 \%$ growth inhibition $\left(\mathrm{IC}_{50}\right.$ and $\left.\mathrm{IC}_{80}\right)$ were determined for all products (Fig. 2). The treatment with 1 showed quite high values of $\mathrm{IC}_{50}$ and $\mathrm{IC}_{80}\left(\mathrm{IC}_{50}=46.2 \pm 1.4\right.$ and $\mathrm{IC}_{80}=50.2 \pm 2.0$ ). For treatment with 2 , the $\mathrm{IC}_{50}$ value was reduced almost to half $\left(\mathrm{IC}_{50}=29.0 \pm 1.7\right.$ and $\left.\mathrm{IC}_{80}=47.4 \pm 2.4\right)$. The treatment with 3 had no effect on cancer cell proliferation, not reaching the $\mathrm{IC}_{50}$ value.

The treatment with 4 had the lowest $\mathrm{IC}_{50}$ value $\left(\mathrm{IC}_{50}=15.3 \pm\right.$ 0.6 and $\mathrm{IC}_{80}=44.3 \pm 3.1$ ), being three times lower than that of its natural precursor (1), and was half that of 2 . These effects could to be related to the increased polarity of the whole molecule, without a significant increase in molecular weight or volume. The compounds $\mathbf{1}, 2$ and 4 that showed cytotoxic effects in the range of concentrations assayed were selected for the rest of the assays: cell-cycle analysis, characterization of apoptosis, changes in mitochondrial membrane potential and Hoechststaining.

The effects of the selected products, 1, 2 and 4 on cell-cycle distribution were investigated to determine a possible cytostatic effect attached to the cytotoxic response. The distribution of cells in different cell-cycle phases was analyzed after $72 \mathrm{~h}$ of 

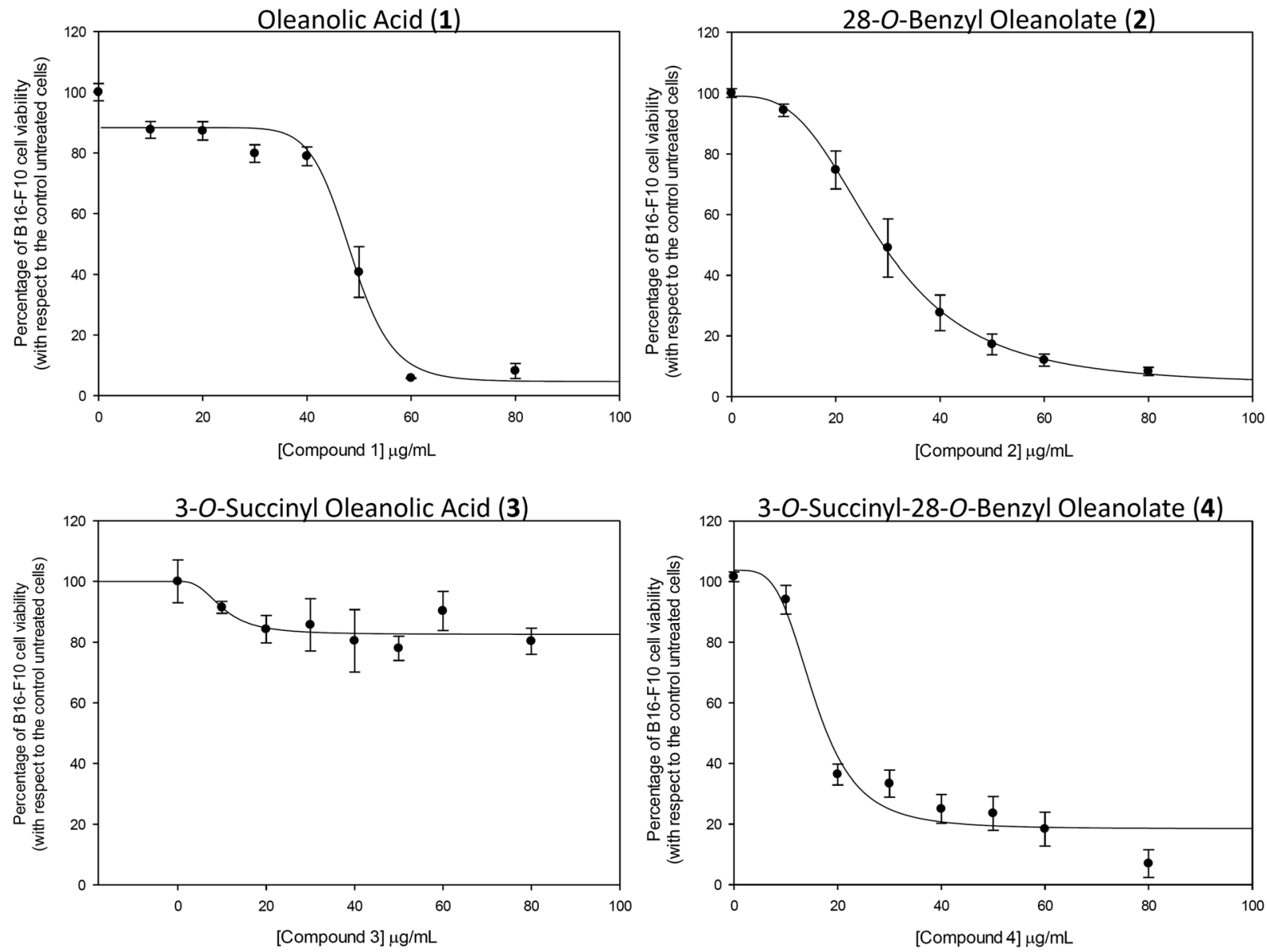

\begin{tabular}{cccccc}
\hline Comp. \# & $\mathbf{R}_{\mathbf{1}}$ & $\mathbf{R}_{\mathbf{2}}$ & $\mathbf{I C}_{\mathbf{5 0}}(\boldsymbol{\mu \mathrm { g }} / \mathrm{mL})$ & $\mathbf{I} \mathbf{C}_{\mathbf{8 0}}(\boldsymbol{\mu g} / \mathrm{mL})$ & $\begin{array}{c}\mathbf{I C}_{50} \text { OA/ } \\
\mathbf{I C}_{50} \text { compound \# }\end{array}$ \\
\hline $\mathbf{1}$ & $\mathrm{H}$ & $\mathrm{H}$ & $46,20 \pm 1,47$ & $50,17 \pm 1,97$ & 1,0 \\
$\mathbf{2}$ & $\mathrm{H}$ & Benzyl & $29,01 \pm 1,66$ & $47,41 \pm 2,42$ & 1,6 \\
$\mathbf{3}$ & Succinyl & $\mathrm{H}$ & $\mathrm{N} / \mathrm{A}$ & $\mathrm{N} / \mathrm{A}$ & -- \\
$\mathbf{4}$ & Succinyl & Benzyl & $15,33 \pm 0,59$ & $44,43 \pm 3,15$ & 3,0 \\
\hline
\end{tabular}

Fig. 2 The effects of oleanolic acid (1), 28-O-benzyl oleanolate (2), 3-O-succinyl oleanolic acid (3), and 3-O-succinyl-28-O-benzyl oleanolate (4), on the viability of B16-F10 murine skin-melanoma cells. After treatment with the compounds for $72 \mathrm{~h}$ in the range of 0 to $80 \mu \mathrm{g} \mathrm{mL}{ }^{-1}$, each point represents the mean value \pm S.D. of at least two independent experiments performed in triplicate. $I C_{50}$ and $I C_{80}$ are the concentrations required for $50 \%$ and $80 \%$ of growth inhibition, respectively.

treatment, by the incorporation of propidium iodide (PI). B16F10 melanoma cells were treated with the products at $\mathrm{IC}_{50}$ and $\mathrm{IC}_{80}$ concentrations, determined previously.

3.2.2. Cell-cycle arrest and distribution. Flow cytometry was used to measure DNA ploidy, as well as alterations in cellcycle profiles. In this way, cell subpopulations with differing DNA content allow the determination of the percentage of cells in each cell-cycle phase. Changes in DNA concentration are characteristic of apoptosis or cell-cycle arrest. DNA histogram analysis revealed that the two derivatives, 2 and $\mathbf{4}$, produced a significant cell-cycle arrest (Fig. 3), increasing the number of cells in the $\mathrm{G}_{0} / \mathrm{G}_{1}$ phase. Compound 2 increased this population up to $68 \%$ at $\mathrm{IC}_{50}$, and $75 \%$ at $\mathrm{IC}_{80}$ concentration. Compound 4 produced a major effect with an increase up to $79 \%$ at $\mathrm{IC}_{50}$, and
$84 \%$ at $\mathrm{IC}_{80}$ concentration. These increases were accompanied by a decrease in the percentage of proliferating cells in the $\mathrm{S}$ phase (up to $25 \%$ for 2 and $16 \%$ for 4 at $\mathrm{IC}_{80}$ concentrations). Changes in the $\mathrm{G}_{2} / \mathrm{M}$ phase were less significant. The cell-cycle arrest observed could also be related to the induction of differentiation by 4 in this cell type.

A wide range of studies in recent years have shown that triterpenoids hinder carcinogenesis by intervening in pathways such as carcinogen activation, DNA repair, cell-cycle arrest, cell differentiation and the induction of apoptosis in cancer cells. ${ }^{\mathbf{1 , 4 5 , 4 6}}$ The identification of new cytotoxic agents that enhance or restore the capability of malignant tumor cells to undergo apoptosis may be crucial for more effective anticancer therapies. ${ }^{1,39,40}$ 


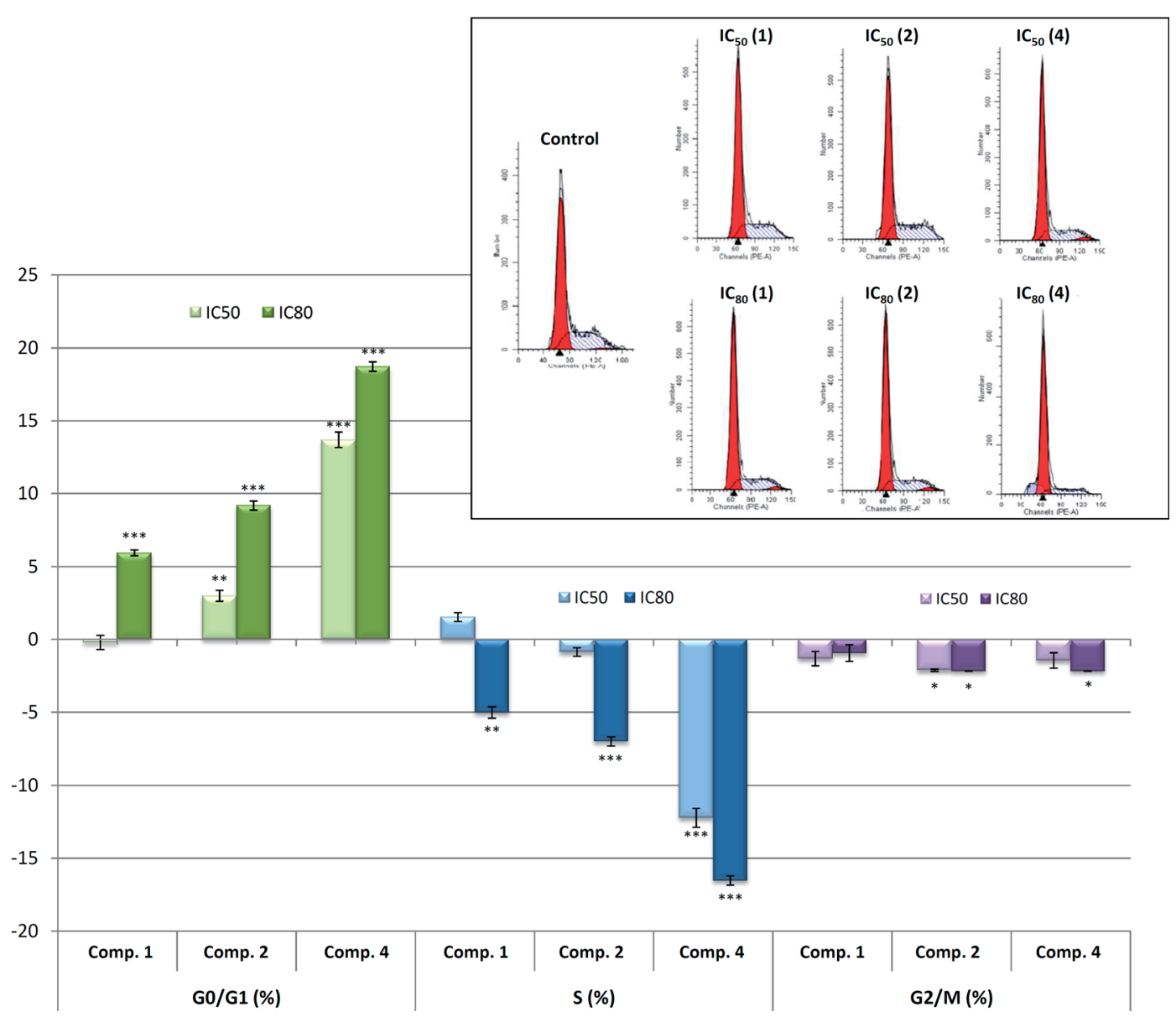

Fig. 3 Top: Histograms of the cell-cycle of B16-F10 skin-melanoma cells $72 \mathrm{~h}$ after treatment with compounds 1,2 and 4 , at $I C_{50}$ and $I C_{80}$ concentrations. Bottom: Increase in the percentage of cells in each cell-cycle phase with respect to untreated control cells. Cell-cycle was conducted after propidium iodide (PI) staining, as described in the Experimental section. Values represent means \pm S.E.M of at least three independent experiments performed in duplicate. Key: $p<0.05(*), p \leq 0.01(* *)$, and $p \leq 0.001(* * *)$, respect to untreated control cells.

Apoptosis is one of the body's most potent defenses against cancer; the pathogenesis of many forms of this degenerative disease is closely connected with aberrantly regulated apoptotic cell death. Different mechanisms that regulate apoptosis associated with mediators that trigger or inhibit cell death have led to the development of therapeutic strategies against cancer.

In most of the pentacyclic triterpenoids, the cytotoxic effects are often accompanied by cytostatic effects. These cytostatic effects are frequently associated with apoptosis induction or differentiation cell process activation. The cell-cycle machinery is an alternative target for the identification of novel biomarkers for cancer detection and prognosis, providing target validation for cell-cycle-directed therapies. As the products $(\mathbf{1}, 2$ and $\mathbf{4})$ inhibited cell growth, we investigated their effect on cell-cycle distribution in B16-F10 skin-melanoma cells after $72 \mathrm{~h}$ of treatment. In this respect, two derivatives, 2 and $\mathbf{4}$, produced cell-cycle arrest in the $\mathrm{G}_{0} / \mathrm{G}_{1}$ phase.

Compound 4 induces greater cell-cycle arrest in the $\mathrm{G}_{0} / \mathrm{G}_{1}$ phase, which is approximately $15 \%$ at $\mathrm{IC}_{50}$ concentration and $20 \%$ at $\mathrm{IC}_{80}$ concentration, coinciding with apoptotic cell death and thus, contributing to the inhibition of cell growth. This could indicate a likely induction of cell differentiation in response to the anti-cancer properties of product 4. Further studies, such as the determination of the expression of the differentiation marker enzymes, would be necessary to assert this point.

3.2.3. Apoptosis induction in B16-F10 murine melanoma cells. Annexin V-FITC staining and PI accumulation were used to determine the percentage of apoptotic cells. Early events in the apoptotic process are loss of plasma membrane asymmetry, accompanied by translocation of phosphatidyl-serine (PS) from the inner to the outer membrane leaflet, thereby exposing PS to the external environment. ${ }^{47}$ The phospholipid-binding protein annexin $\mathrm{V}$ has a high affinity for PS and binds to cells fluorescently labelled with FITC (fluorescein isothiocyanate). The percentages of apoptosis, as determined with annexin V-FITC/PI flow cytometry analysis are shown in Fig. 4.

Assessment of apoptosis in B16-F10 cells was performed 72 $\mathrm{h}$ after treatment with the compounds $\mathbf{1 , 2}$ and $\mathbf{4}$ at $\mathrm{IC}_{50}$ and $\mathrm{IC}_{80}$ concentrations. FACS analysis using Annexin V-FITC staining and PI accumulation was used to differentiate normal cells (Annexin- $\mathrm{V}^{-}$and $\mathrm{PI}^{-}$), early apoptotic cells (Annexin- $\mathrm{V}^{+}$and $\mathrm{PI}^{-}$), late apoptotic cells (Annexin- $\mathrm{V}^{+}$and $\mathrm{PI}^{+}$) and necrotic cells (Annexin- $\mathrm{V}^{-}$and $\mathrm{PI}^{+}$). 

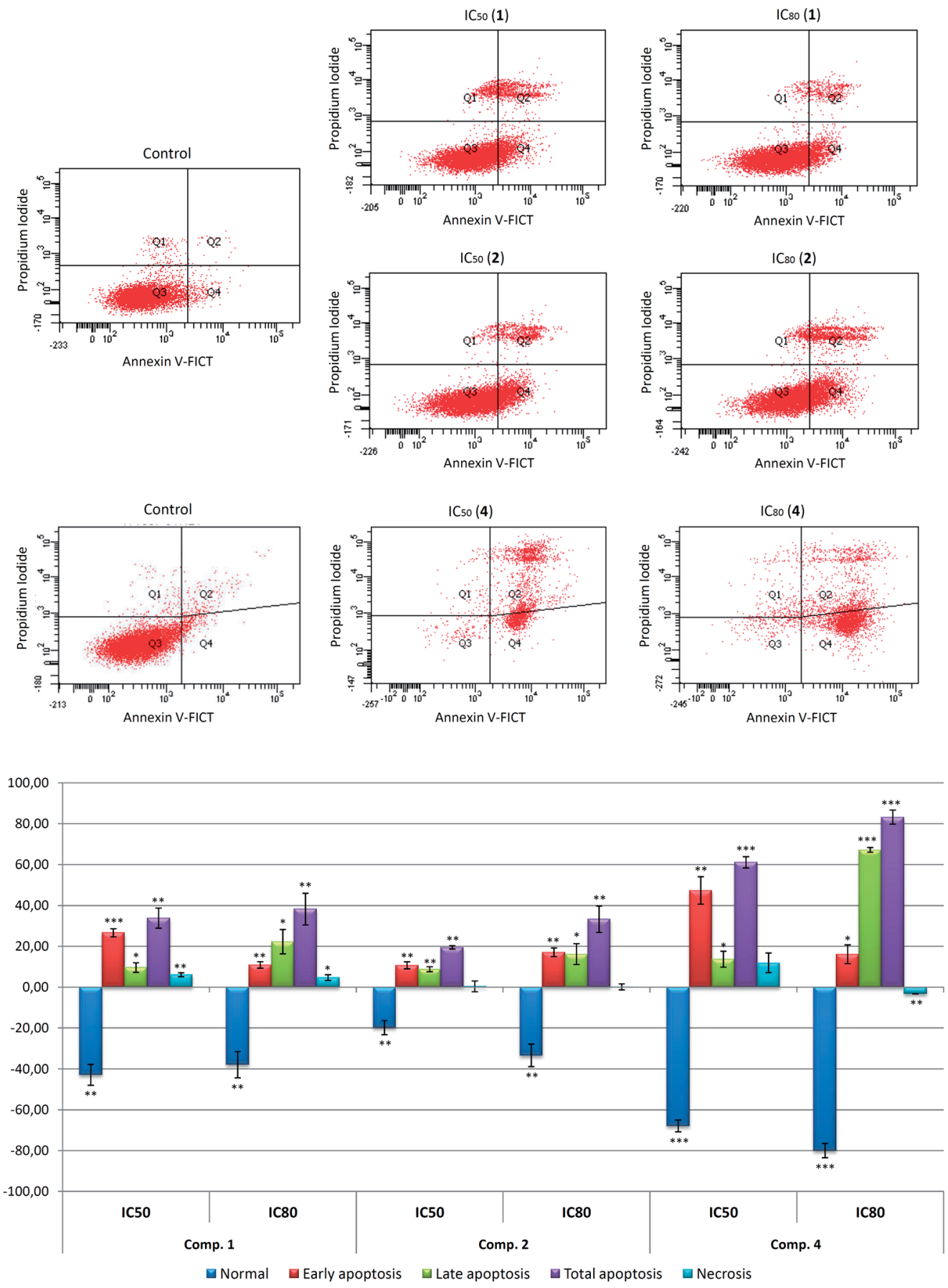

Fig. 4 Effects of compounds 1,2 , and 4 on apoptosis in B16-F10 skin-melanoma cells, after $72 \mathrm{~h}$ treatment, at IC 50 and IC 80 concentrations. Top: Diagrams of annexin V/propidium iodide (IP) flow cytometry. B16-F10 cells were labeled with annexin V-FICT/PI as described in Experimental section. The right quadrants of each diagram represent apoptotic cells (Q2, late apoptosis; Q4, early apoptosis). Early apoptotic cells were annexin $\mathrm{V}^{+} \mathrm{PI}^{-}$, whereas late apoptotic cells were annexin $\mathrm{V}^{+}, \mathrm{PI}^{+}$. Bottom: Flow cytometry analysis of Annexin $\mathrm{V}-\mathrm{FITC}$ staining and $\mathrm{PI}$ accumulation, values represent means \pm S.E.M of three experiments in duplicate. Key: $p<0.05(*), p \leq 0.01(* *)$, and $p \leq 0.001(* * *)$, respect to untreated control cells.

The three compounds demonstrated apoptotic effects on the treated cells, with high percentage of total apoptosis (early apoptotic together with late apoptotic cells), reaching an $\mathrm{IC}_{50}$ concentration of $42 \%$ (28.1\% early apoptosis and $16.4 \%$ late apoptosis) in response to compound $1,28 \%$ (12.2\% early apoptosis and $29.1 \%$ late apoptosis) for compound 2, and $69 \%$
(48.8\% early apoptosis and $20.5 \%$ late apoptosis) for compound 4.

At $\mathrm{IC}_{80}$ concentration, these percentages were $47 \%(12.4 \%$ early and $29.1 \%$ late apoptosis) for 1, 42\% (18.6\% early apoptosis and $23 \%$ late apoptosis) for 2 , and $92 \%$ (16.6\% early apoptosis and $73.9 \%$ late apoptosis) in the treatment with 4 . In 

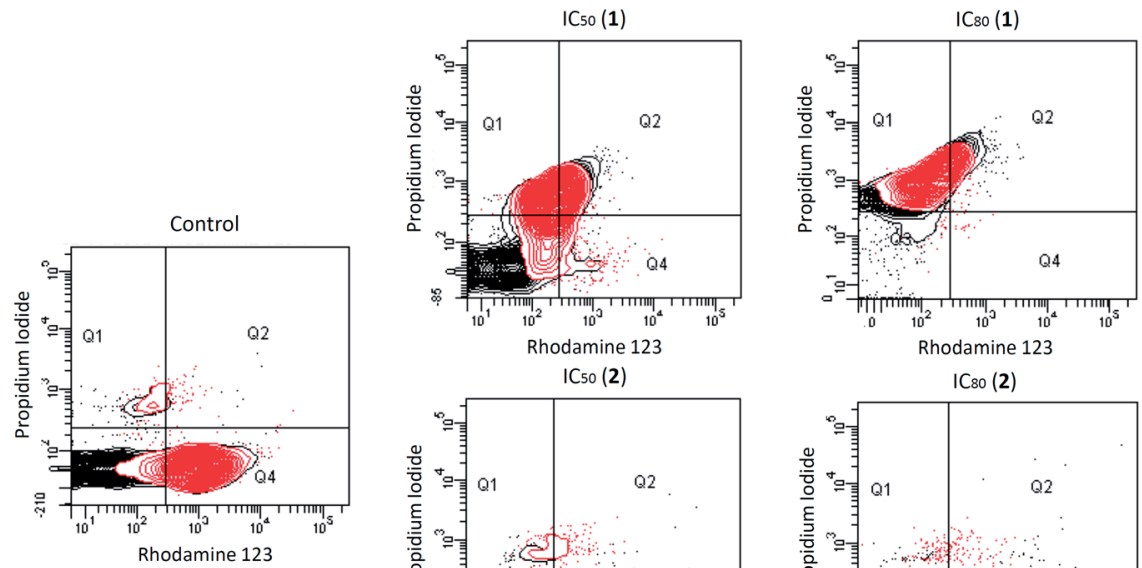

IC50 (2)

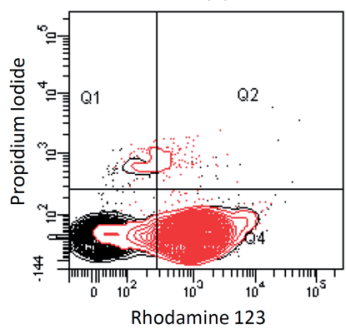

IC80 (2)

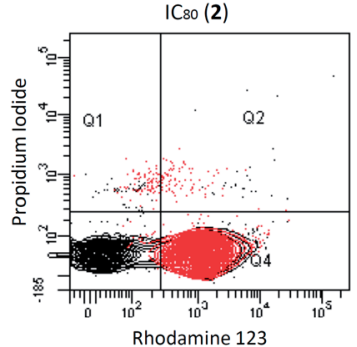

IC50 (4)
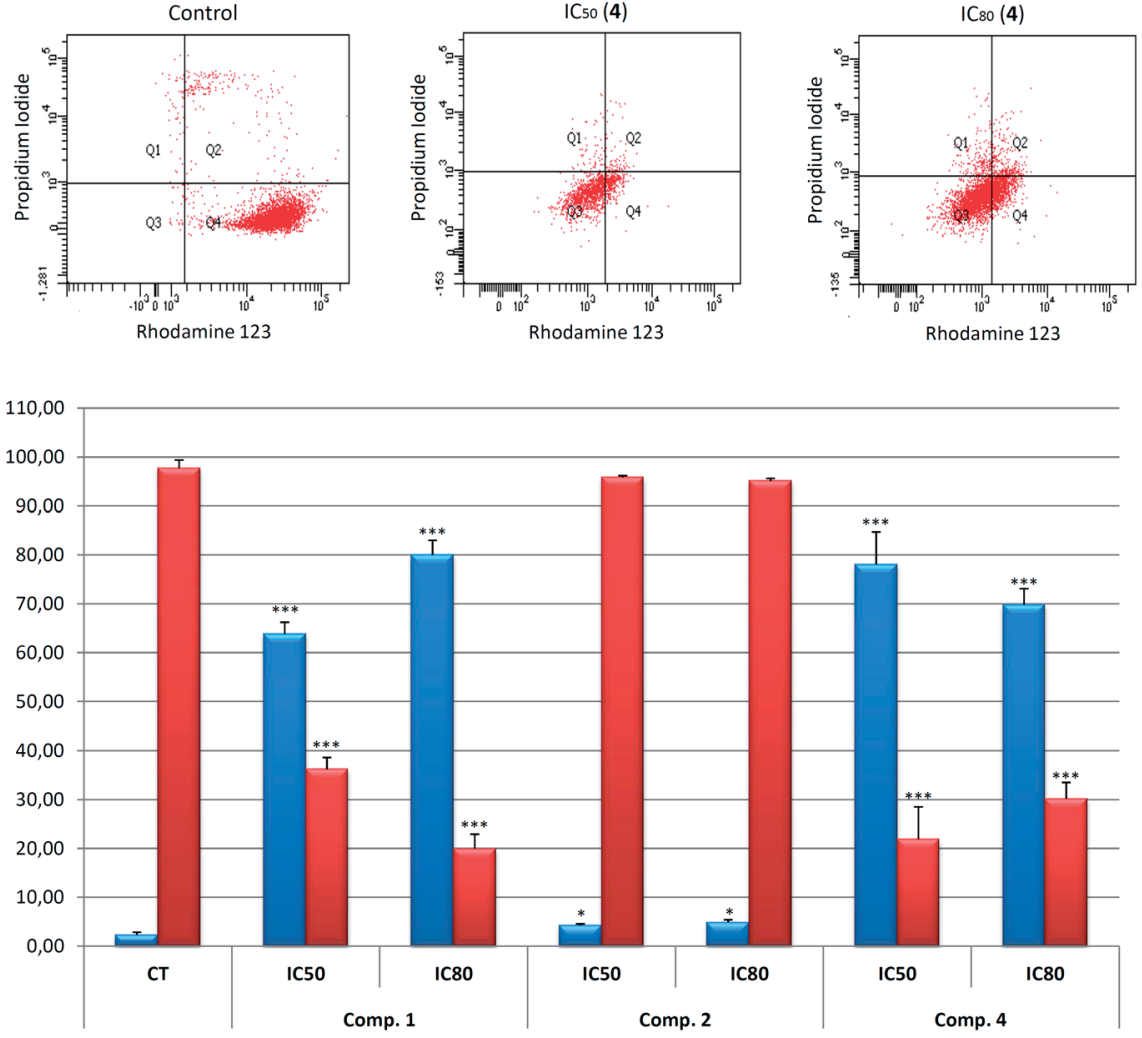

Rhodamine 123 - $\quad$ Rhodamine $123+$

Fig. 5 Effects of compounds 1, 2, and 4 on mitochondrial membrane potential in B16-F10 skin-melanoma cells, after $72 \mathrm{~h}$ treatment, at IC 50 and $\mathrm{IC}_{80}$ concentrations. Top: Diagram of rhodamine 123/propidium iodide flow-cytometry. B16-F10 cells were labeled with Rh123/IP as described in Experimental section. The right quadrants of each diagram (Q2 and Q4) represent positive cells stained with Rh123. Bottom: Percentage of Rh123 positive and negative B16-F10 cell population, in comparison with untreated control cells (CT). Values are expressed as means \pm S.E.M of three experiments in duplicate. Key: $p<0.05(*), p \leq 0.01(* *)$, and $p \leq 0.001(* * *)$, respect to untreated control cells.

addition, the percentages of the necrotic population were not noteworthy. The apoptotic effect in response to 4, with the lowest $\mathrm{IC}_{50}$ concentration was the most significant.

In most cases, the highest percentage of apoptosis was achieved at $\mathrm{IC}_{80}$ concentrations. In all cases, the number of apoptotic cells increased concomitantly with dose concentration. The low values of $\mathrm{IC}_{50}$ concentrations and good percentages of apoptosis attained by these derivatives, especially by $\mathbf{4}$, show that they could be used as promising anticancer drugs; further studies will be necessary to strengthen this point.

The apoptotic process frequently does not function in tumor cells. The intrinsic and extrinsic apoptotic activation routes have been described in the apoptotic effect of numerous 


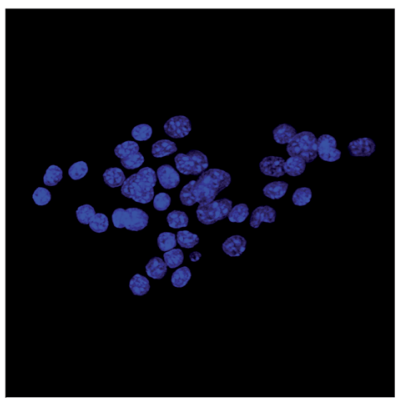

Control

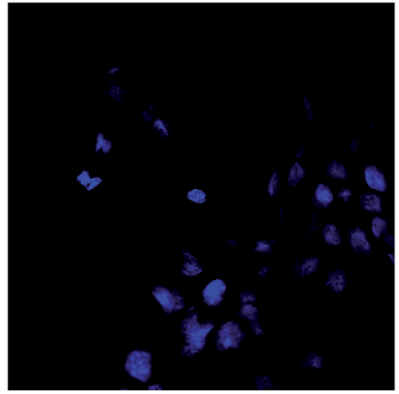

Comp. 2

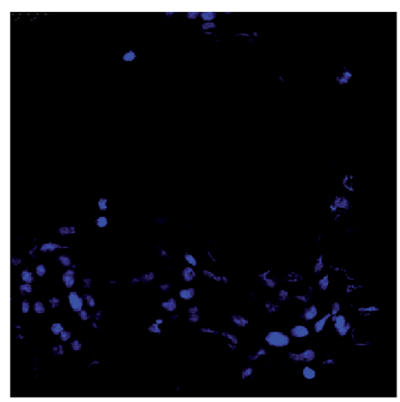

Comp. 1

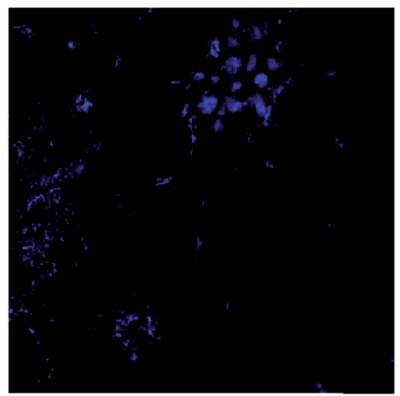

Comp. 4
Fig. 6 Morphology changes in B16-F10 skin-melanoma cells after exposure to compounds 1,2 and 4 for $72 \mathrm{~h}$, at $\mathrm{IC}_{50}$ concentrations. The samples were prepared with mounting medium, Mowiol, and the cells were examined using fluorescence microscopy following Hoechst-staining as described in Experimental section.

triterpenoids, such as maslinic acid, ursolic acid, betulinic acid, OA and its derivatives. ${ }^{\mathbf{1 - 3 , 5}}$ With alterations to the Bcl-2 protein family balance, loss of mitochondrial membrane potential, and the release of mitochondrial cytochrome- $c$ occur. ${ }^{\mathbf{4 8 , 4 9}}$

3.2.4. Mitochondrial membrane potential disturbances. Mitochondria constitute a key target in synthetic and natural triterpenoids. ${ }^{50}$ Pentacyclic triterpene compounds have proved to be able to activate the intrinsic apoptotic pathway, mediated by mitochondrial disruption..$^{2,3,51}$ In a first approximation of molecular mechanism, we analyzed the mitochondrialmembrane potential (MMP). Changes in this membrane potential can be associated with the intrinsic mechanism of apoptosis activation, while apoptosis induction without MMP changes may suggest activation of the extrinsic apoptotic pathway.

We investigated the MMP to determine the possible mechanism involved in the apoptotic responses. The changes in MMP were analyzed by monitoring the cell fluorescence following double staining with Rh123 and PI. Rh123 is a membrane-permeable fluorescent cationic dye that is selectively taken up by mitochondria, and directly proportional to MMP. ${ }^{52}$

Changes in MMP were analyzed by flow-cytometry staining with Rh123/IP after treatment with the compounds 1, 2, and 4 for $72 \mathrm{~h}$, at $\mathrm{IC}_{50}$ and $\mathrm{IC}_{80}$ concentrations. The apoptosis induction by 2 did not produce any changes in MMP, suggesting that the apoptosis was triggered by the extrinsic apoptotic pathway activation. Compounds 1 and 4 clearly produced MMP disturbances with loss of MMP and negative Rh123 staining.
The treatment with these products showed a decrease in the Rh123 positive cells stained, $63.8 \%$ at $\mathrm{IC}_{50}$ and $80.1 \%$ at $\mathrm{IC}_{80}$ concentrations for 1 , and $78.1 \%$ at $\mathrm{IC}_{50}$ and $69.8 \%$ at $\mathrm{IC}_{80}$ concentration in response to $\mathbf{4}$, with a concomitant increase in Rh123 negative cells stained (Fig. 5). Therefore, the mitochondrial disruption, together with apoptosis, could indicate the activation of the intrinsic apoptotic route in the B16-F10 cell line in response to $\mathbf{1}$ and $\mathbf{4}$. Nevertheless, no changes in mitochondrial potential were observed following treatment with 2 .

These results clearly show mitochondrial disturbances following treatment with 1 and 4 in B16-F10 murine melanoma cells, which could be related to the activation of the mitochondrial or intrinsic apoptotic pathway by these products. Further molecular studies will be necessary to confirm this assertion.

3.2.5. Morphological apoptotic changes. The Hoechst procedure stains nuclei that contain nicked DNA, a characteristic exhibited by cells in apoptotic cell death. Fluorescence microscopy can determine changes in the cell morphology. The fluorescence microscopic observations showed that a significant number of cells treated with the selected compounds acquired apoptotic features (Fig. 6).

The morphological analysis of Hoechst-stained cells in B16F10 cells indicated that they had undergone remarkable morphological changes. After 72 h of exposure to compounds $\mathbf{1}$, 2 , and 4 (at $\mathrm{IC}_{50}$ and $\mathrm{IC}_{80}$ concentrations), the cells showed typical apoptotic changes, including cell shrinkage, chromatin condensation, and the loss of normal nuclear architecture. Fluorescence microscopic observation after Hoechst staining showed that a significant number of cells treated with compound $\mathbf{4}$ acquired apoptotic features, as evident from nuclear fragmentation, and the prominent disruption of the cell-membrane integrity.

\section{Conclusions}

This study is the first to investigate the apoptotic effects of the oleanolic acid derivatives, 2, 3 and 4, in comparison to their natural precursor. Our data provide evidence that these products exert anti-proliferative and pro-apoptotic effects on B16F10 skin-melanoma cells, a model for malignant melanoma cells. Moreover, they induce morphological changes that are characteristic of apoptosis, such as chromatin condensation and fragmentation, as well as cell shrinkage and loss of cellmembrane asymmetry, as demonstrated by fluorescence microscopy. These effects are greater in response to $\mathbf{4}$, compared to its precursor, with smaller $\mathrm{IC}_{50}$ and $\mathrm{IC}_{80}$ values and a greater percentage of apoptosis induction. In conclusion, the 3-O-succinyl-28-O-benzyl oleanolate (4), a novel oleanolic acid derivative, is able to induce apoptosis in murine skinmelanoma cells, probably via the intrinsic mitochondrial pathway. The precise molecular signaling pathway by which this compound induces apoptosis needs to be investigated. Nevertheless, our data could contribute to the development of this compound and related compounds for use as cancer chemotherapeutics or chemopreventive agents. The apoptotic potency 
of 4 suggests that it may be an effective compound in the prevention or treatment of skin-melanoma.

\section{Authors' contribution}

Fernando J. Reyes-Zurita, Andrés Parra and José A. Lupiáñez conceived and designed the study protocol. Fernando J. ReyesZurita, Marta Medina-O'Donnell, Rosa M. Ferrer-Martín, Eva E. Rufino-Palomares, Amalia Pérez-Jiménez, Leticia GarcíaSalguero, Khalida Mokhtari, Juan Peragón, Pedro P. Medina and José A. Lupiáñez performed all cell culture (in vitro) and other biological experiments. Samuel Martín-Fonseca, Francisco Rivas, Antonio Martínez, Andrés García-Granados and Andrés Parra performed all the synthesis and purification experiments of SBOA and OA. Fernando J. Reyes-Zurita, Marta Medina-O'Donnell, Rosa M. Ferrer-Martín, Eva E. RufinoPalomares, Amalia Pérez-Jiménez, Khalida Mokhtari, Leticia García-Salguero and Pedro P. Medina contributed to reagents, materials, and analysis tools. Fernando J. Reyes-Zurita, Eva E. Rufino-Palomares, Leticia García-Salguero, Juan Peragón, Pedro P. Medina, Andrés Parra and José A. Lupiáñez conducted the data analysis. Fernando J. Reyes-Zurita, Andrés Parra and José A. Lupiáñez contributed to the paper preparation.

\section{Acknowledgements}

This study was supported by grants Group BIO 157 from the Technology and Innovation Council of the Andalucian regional government and AGL2006-12210-C03-02/ALI, SAF2005-01627, ISCIII-RTICC (RD06/0020/0046) from the Spanish government and European Union FEDER funds.

\section{References}

1 F. J. Reyes, J. J. Centelles, J. A. Lupiáñez and M. Cascante, FEBS Lett., 2006, 580, 6302-6310.

2 F. J. Reyes-Zurita, E. E. Rufino-Palomares, J. A. Lupiáñez and M. Cascante, Cancer Lett., 2009, 273, 44-54.

3 F. J. Reyes-Zurita, G. Pachon-Pena, D. Lizarraga, E. E. RufinoPalomares, M. Cascante and J. A. Lupiáñez, BMC Cancer, 2011, 11, 154.

4 S. Sanchez-Tena, F. J. Reyes-Zurita, S. Diaz-Moralli, M. P. Vinardell, M. Reed, F. Garcia-Garcia, J. Dopazo, J. A. Lupiáñez, U. Gunther and M. Cascante, PLoS One, 2013, 8, e59392.

5 F. J. Reyes-Zurita, E. E. Rufino-Palomares, P. P. Medina, E. Leticia Garcia-Salguero, J. Peragon, M. Cascante and J. A. Lupiáñez, Biochimie, 2013, 95, 2157-2167.

6 E. E. Rufino-Palomares, A. Pérez-Jiménez, F. J. Reyes-Zurita, L. García-Salguero, K. Mokhtari, A. Herrera-Merchán, P. P. Medina, J. Peragón and J. A. Lupiáñez, Curr. Org. Chem., 2015, 19, 919-947.

7 J. Peragón, E. E. Rufino-Palomares, I. Muñoz-Espada, F. J. Reyes-Zurita and J. A. Lupiáñez, Int. J. Mol. Sci., 2015, 16, 21681-21694.
8 F. J. Reyes-Zurita, E. E. Rufino-Palomares, L. García-Salguero, J. Peragón, P. P. Medina, A. Parra, M. Cascante and J. A. Lupiáñez, PLoS One, 2016, 11, e0146178.

9 E. Rufino-Palomares, F. J. Reyes-Zurita, C. A. FuentesAlmagro, M. de la Higuera, J. A. Lupiáñez and J. Peragón, Proteomics, 2011, 11, 3312-3325.

10 E. E. Rufino-Palomares, F. J. Reyes-Zurita, L. GarcíaSalguero, K. Mokhtari, P. P. Medina, J. A. Lupiáñez and J. Peragón, J. Proteomics, 2013, 83, 15-25.

11 S. Schwarz, A. Loesche, S. D. Lucas, S. Sommerwerk, I. Serbian, B. Siewert, E. Pianowski and R. Csuk, Eur. J. Med. Chem., 2015, 103, 438-445.

12 K. Mokhtari, E. E. Rufino-Palomares, A. Pérez-Jiménez, F. J. Reyes-Zurita, C. Figuera, L. García-Salguero, P. P. Medina, J. Peragón and J. A. Lupiáñez, Evidence-Based Complementary Altern. Med., 2015, 2015, 272457.

13 M. Cascante, S. Sanchez-Tena, D. Lizarraga, M. A. Reed, J. B. Carrigan, S. Diaz-Moralli, G. Alcarraz-Vizan, F. J. Reyes-Zurita, J. J. Centelles, M. P. Vinardell, J. A. Lupiáñez, V. Noe, C. J. Ciudad, J. L. Torres and U. Gunther, FEBS J., 2013, 280, 628-629.

14 A. Pérez-Jiménez, E. E. Rufino-Palomares, N. FernándezGallego, M. C. Ortuño-Costela, F. J. Reyes-Zurita, J. Peragón, L. García-Salguero, K. Mokhtari, P. P. Medina and J. A. Lupiáñez, Phytomedicine, 2016, 23, 1301-1311.

15 E. E. Rufino-Palomares, F. J. Reyes-Zurita, L. GarcíaSalguero, J. Peragón, M. de la Higuera and J. A. Lupiáñez, Comp. Biochem. Physiol., Part C: Toxicol. Pharmacol., 2016, 187, 32-42.

16 M. Fernandez-Navarro, J. Peragon, F. J. Esteban, M. de la Higuera and J. A. Lupiáñez, Comp. Biochem. Physiol., Part C: Toxicol. Pharmacol., 2006, 144, 130-140.

17 M. Fernandez-Navarro, J. Peragon, V. Amores, M. de la Higuera and J. A. Lupiáñez, Comp. Biochem. Physiol., Part C: Toxicol. Pharmacol., 2008, 147, 158-167.

18 M. Fernández-Navarro, J. Peragón, F. J. Esteban, V. Amores, M. de la Higuera and J. A. Lupiáñez, in Olives and olive oil in health and disease prevention, ed. V. R. Perry and R. R. Watson, Elsevier Inc, London, England, 2009, ch. 157, pp. 1415-1421.

19 E. E. Rufino-Palomares, F. J. Reyes-Zurita, L. GarcíaSalguero, J. Peragón, M. de la Higuera and J. A. Lupiáñez, Aquacult. Nutr., 2012, 18, 138-151.

20 E. E. Rufino-Palomares, F. J. Reyes-Zurita, L. GarcíaSalguero, J. Peragón, M. de la Higuera and J. A. Lupiáñez, Aquacult. Nutr., 2012, 18, 568-580.

21 E. E. Rufino-Palomares, F. J. Reyes-Zurita, L. GarciaSalguero, J. Peragon, M. de la Higuera and J. A. Lupiáñez, Aquacult. Nutr., 2013, 19, 709-720.

22 E. E. Rufino-Palomares, J. Peragón, F. J. Reyes-Zurita, L. García-Salguero and J. A. Lupiáñez, FEBS J., 2012, 279, 229-230.

23 R. Thimmappa, K. Geisler, T. Louveau, P. O'Maille and A. Osbourn, Annu. Rev. Plant Biol., 2014, 65, 225-257.

24 W. S. Kombargi, S. E. Michelakis and C. A. Petrakis, J. Econ. Entomol., 1998, 91, 993-998. 
25 R. A. Hill and J. D. Connolly, Nat. Prod. Rep., 2015, 32, 273327.

26 H. Tokuda, H. Ohigashi, K. Koshimizu and Y. Ito, Cancer Lett., 1986, 33, 279-285.

27 M. K. Shanmugam, X. Dai, A. P. Kumar, B. K. Tan, G. Sethi and A. Bishayee, Cancer Lett., 2014, 346, 206-216.

28 K. T. Liby and M. B. Sporn, Pharmacol. Rev., 2012, 64, 9721003.

29 M. Medina-O'Donnell, F. Rivas, F. J. Reyes-Zurita, A. Martinez, S. Martin-Fonseca, A. Garcia-Granados, R. M. Ferrer-Martin, J. A. Lupiáñez and A. Parra, Eur. J. Med. Chem., 2016, 118, 64-78.

30 A. Parra, S. Martín-Fonseca, F. Rivas, F. J. Reyes-Zurita, M. Medina-O'Donnell, E. E. Rufino-Palomares, A. Martínez, A. García-Granados, J. A. Lupiáñez and F. Albericio, ACS Comb. Sci., 2014, 16, 428-447.

31 A. Parra, S. Martin-Fonseca, F. Rivas, F. J. Reyes-Zurita, M. Medina-O'Donnell, A. Martinez, A. Garcia-Granados, J. A. Lupiáñez and F. Albericio, Eur. J. Med. Chem., 2014, 74, 278-301.

32 R. Rodriguez-Rodriguez, Curr. Med. Chem., 2015, 22, 14141425.

33 Z. Du, Z. Liu, Z. Ning, Y. Liu, Z. Song, C. Wang and A. Lu, Planta Med., 2015, 81, 259-271.

34 R. Csuk, Expert Opin. Ther. Pat., 2014, 24, 913-923.

35 X. Wang, Genes Dev., 2001, 15, 2922-2933.

36 S. Y. Sun, N. Hail Jr and R. Lotan, J. Natl. Cancer Inst., 2004, 96, 662-672.

37 A. Ashkenazi, Cytokine Growth Factor Rev., 2008, 19, 325-331. 38 O. Micheau and J. Tschopp, Cell, 2003, 114, 181-190.
39 A. Garcia-Granados, P. C. T. Int. Appl, WO 9804331, 1998 Chem. Abstr., 1998, 128, 179706.

40 A. Garcia-Granados, A. Martinez, J. N. Moliz, A. Parra and F. Rivas, Molecules, 1998, 3, M88.

41 R. Weis and W. Seebacher, Magn. Reson. Chem., 2002, 40, 455-457.

42 J. Yang, J. W. Quail and Z. C. Jia, Acta Crystallogr., Sect. C: Cryst. Struct. Commun., 1997, 53, 349-351.

43 I. J. Fidler, Cancer Res., 1975, 35, 218-224.

44 I. J. Fidler and C. Bucana, Cancer Res., 1977, 37, 3945-3956.

45 P. Dzubak, M. Hajduch, D. Vydra, A. Hustova, M. Kvasnica, D. Biedermann, L. Markova, M. Urban and J. Sarek, Nat. Prod. Rep., 2006, 23, 394-411.

46 T. Ikeda, M. Sporn, T. Honda, G. W. Gribble and D. Kufe, Cancer Res., 2003, 63, 5551-5558.

47 K. Takano, Y. Nakamura and Y. Yoneda, Neuroscience, 2003, 120, 961-967.

48 P. O. Harmand, R. Duval, C. Delage and A. Simon, Int. J. Cancer, 2005, 114, 1-11.

49 V. Zuco, R. Supino, S. C. Righetti, L. Cleris, E. Marchesi, C. Gambacorti-Passerini and F. Formelli, Cancer Lett., 2002, 175, 17-25.

50 A. Petronelli, G. Pannitteri and U. Testa, Anticancer Drugs, 2009, 20, 880-892.

51 R. Martin, J. Carvalho-Tavares, E. Ibeas, M. Hernandez, V. Ruiz-Gutierrez and M. L. Nieto, Cancer Res., 2007, 67, 3741-3751.

52 R. K. Emaus, R. Grunwald and J. J. Lemasters, Biochim. Biophys. Acta, 1986, 850, 436-448. 